\title{
The Sustainability Matrix: A Tool for Integrating and Assessing Sustainability in the Bachelor and Master Theses of Engineering Degrees
}

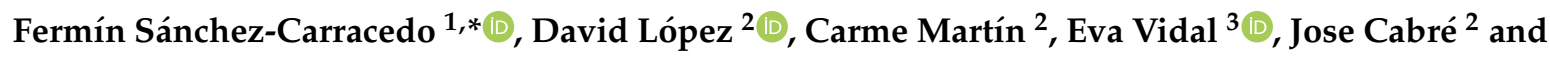 \\ Joan Climent ${ }^{2}$ \\ 1 Barcelona School of Informatics, University Research Institute for Sustainability Science and Technology, \\ UPC-BarcelonaTech, 08034 Barcelona, Spain \\ 2 Barcelona School of Informatics, UPC-BarcelonaTech, 08034 Barcelona, Spain; david@ac.upc.edu (D.L.); \\ martin@essi.upc.edu (C.M.); jose.cabre@upc.edu (J.C.); juan.climent@upc.edu (J.C.) \\ 3 Barcelona School of Telecommunications Engineering, UPC-BarcelonaTech, 08034 Barcelona, Spain; \\ eva.vidal@upc.edu \\ * Correspondence: fermin@ac.upc.edu
}

Received: 25 May 2020; Accepted: 15 July 2020; Published: 17 July 2020

\begin{abstract}
It is vital that subjects such as the circular economy, sustainable design, green computing or environmental engineering be included in the engineering curriculum. Education for sustainable development will enable engineers to develop sustainable products and provide sustainable services, thereby leading to a beneficial result for society and making an indispensable contribution to the Sustainable Development Goals achievement. As the last stage for students in academia, Degree Theses (Bachelor's and Master's) provide a good tool for reviewing the sustainability competencies developed during the degree, as well as being an opportunity for applying these competencies in a holistic way. In their Degree Theses, students should be able to demonstrate that they are aware of the need to introduce and assess sustainability in their future engineering projects. This paper presents a guide aimed at helping engineering students to design and develop sustainable projects, and analyzes the first results of its use in two schools of the Universitat Politècnica de Catalunya-BarcelonaTech. The proposal is based on a tool referred to as "the Sustainability Matrix", in which cells contain questions that engineering students should take into account when undertaking their Degree Theses. The questions are related to the project development, the project exploitation and the possible risks involved, three aspects in accordance with the sustainability dimensions (economic, environmental and social). The Sustainability Matrix helps students to develop sustainable projects when they graduate, and teachers to assess how sustainability is incorporated across the curriculum in the subjects they teach and in the students' Degree Theses.
\end{abstract}

Keywords: sustainability; sustainable development; education for sustainable development; sustainability assessment; engineering projects; engineering degrees; sustainability in bachelor's thesis; sustainability in master's thesis

\section{Introduction}

The sustainability competency is closely related to the sustainable development concept. The Brundtland Commission [1] defines sustainable development as "the ability to satisfy today's needs without compromising the ability of future generations to satisfy their own needs, which is a matter of intergenerational justice." Both the Brundtland Commission and the Sustainable Development Goals (SDG) of the United Nations [2] define social equality, environmental protection and economic growth as the pillars on which sustainable development is based. In order to achieve the "intergenerational 
justice" indicated by the Brundtland Commission, these pillars must be introduced at all study levels, particularly in higher education.

In 2017, UNESCO published the document “Education for the Sustainable Development Goals. Learning Objectives" [3], which defines more precisely the goals to be achieved for each one of the 17 SDGs. These goals must be developed by both public agencies and private companies, which are obliged to include sustainable development in their daily work.

Corporate reporting is one of the objectives of the SDG. Goal 12.6 is "Encourage companies, especially large and transnational companies, to adopt sustainable practices and to integrate sustainability information into their reporting cycle". Only those factors that can be identified and measured can be reviewed in order to obtain an improvement. This should be the objective of a sustainability report, showing the contribution of the company's activity to the SDG.

Nowadays, a sustainability report is a usual requirement for companies and their projects. In Europe, for example, the Directive 2014/95/EU of the European Parliament and of the Council of 22 October 2014 [4] amending Directive 2013/34/EU [5], regarding disclosure of non-financial and diversity information by certain large undertakings, indicates that public-interest companies with more than 500 employees shall include in their management report a non-financial statement containing information relating at the very least to environmental, social and employee matters, respect for human rights, anti-corruption and bribery. Prestigious organizations such as the Global Reporting Initiative (GRI) measure or audit the impact on sustainability of the products and services of several companies. For example, in [6] the GRI organization defines standards for reporting on the impact of a company on climate change, human rights, transparency or quality of life, among other aspects. The document "Can corporate reporting help end poverty?" [7] provides numerous arguments on how the fact that companies report and try to improve their results in the environmental and social spheres contributes directly and indirectly to the achievement of SDG 1: "End of poverty". According to the KPMG Survey of Corporate Responsibility Reporting [8], 93\% of the 250 largest corporations in the world issue a sustainability report [6]. Indeed, the GRI database contains more than 50,000 reports from more than 13,000 companies and organizations.

Although a broad consensus exists that sustainable development constitutes one of the great challenges in this century, sustainability often appears to be a difficult competency to introduce into higher-education curricula due to the lack of involvement by professors, mainly because of their scant knowledge about this competency [9] and the insufficient awareness of social capital, even in the university environment [10]. In recent years, numerous academic and investor studies [11,12] have found that companies that integrate key environmental, social and governance factors, together with a rigorous financial analysis, achieve a higher performance. However, it is obvious that building a sustainable conscience is a huge undertaking. Managing and implementing sustainability requires the commitment of all stakeholders and new ways of working, thinking and learning [13].

A good example is the Vallés School of Architecture (EAV) of the Universitat Politècnica de Catalunya-BarcelonaTech (UPC), which issued an internal report that showed the importance of sustainability training of its graduates. According to this report, the construction of the school building generated an impact on climate change equivalent to 150 tons of $\mathrm{CO}_{2}\left(\mathrm{tCO}_{2}\right)$, while utility services (lighting, heating, etc.) generate annually the equivalent of $370 \mathrm{tCO}_{2}$. From the sustainability point of view, the conclusion reached was that it is more important to consider the subsequent life of the building than its actual construction. Extrapolating this data to an engineering project, one may assume that the sustainability of the project during its lifetime may be more significant than a sustainable design, and the implementation and implantation of the project (although this is not always the case).

The EAV is located on the outskirts of the city, and the school is not as well connected as it would be if it were situated in or near the city center. The consequent travel to and from the university by users generates annually a total of $750 \mathrm{tCO}_{2}$. Location in a different place, or the availability of a more sustainable public transport system, would therefore have a greater impact on school sustainability than making the everyday use of the building more sustainable. 
Notwithstanding, the most shocking figures in the study numbers are revealed when the environmental impact produced by school graduates is evaluated. The report estimates that graduates would design buildings that consume annually more than 2,250,000 t $\mathrm{CO}_{2}$. In other words, providing students with an education that integrates sustainability would have an even greater impact than the best school design, even though the geographical location of the building were to change.

In the light of this study, one may assume that sustainability is not merely a personal choice for an engineer: it is a professional necessity. Even though an engineer may act sustainably as an individual by reducing his or her own consumption, separating garbage and recycling, switching to a less polluting form of transport or collaborating with an NGO, the greatest impact engineers have on society and the environment is through their professional activity as engineers. Sustainability must be integrated in all engineering degrees. A good example are ICT degrees. ICT products and services are currently responsible for $2 \%$ of global carbon emissions [14] and the International Telecommunication Union [15] has estimated the contribution of ICT (excluding the broadcasting sector) to climate change at between $2 \%$ and $2.5 \%$ of total global carbon emissions. On the other hand, ICT has the potential to reduce global greenhouse gas emissions by $20 \%$ by 2030 through helping companies and individuals to use and save energy more intelligently [16]. In conclusion, it is vital for ICT engineers to be aware of the impact their work can have for building a more sustainable world.

Higher education standards around the world take into account sustainable development. The Accreditation Board for Engineering and Technology (ABET) accreditation system [17] defines, among others, the following skills for a program to be accredited:

- Sustainability awareness

- A grasp of professional and ethical responsibility

- A broad understanding of the impact that engineering solutions have on the global, economic, environmental and social context.

The Tuning project [18] is the European standard for defining generic competencies in the European Higher Education Area (EHEA). The Tuning project sets out 31 generic competencies, five of which are directly related to sustainable development (C6, C17, C23, C25 and C28), and three indirectly related (C22, C29 and C30):

- C6: Ability to show awareness of equal opportunities and gender issues

- C17: Ability to act on the basis of ethical reasoning

- C23: Ability to act with social responsibility and civic awareness

- C25: Appreciation of and respect for diversity and multiculturalism,

- C28: Commitment to the conservation of the environment

- C22: Ability to design and manage projects

- C29: Ability to adapt to and act in new situations

- C30: Ability to evaluate and maintain the quality of work produced.

Consequently, both in the USA and in Europe, ongoing initiatives are being undertaken to promote the integration of competencies concerning sustainable development in higher education. The work presented in this paper proposes a way of developing these competencies in the curricula of Engineering Degrees.

Just as engineers should include sustainability in their projects, graduates should also demonstrate that they are able to do the same before leaving university. Students should therefore include a sustainability analysis in their Degree Thesis (DT), either the Bachelor's Thesis (BT) or the Master's Thesis (MT), by using all the knowledge they have acquired throughout the degree course. This paper addresses how to introduce and assess sustainability in the DT of Engineering Degrees. This proposal can also be readily adapted to the DT of other degrees different from engineering. Also, as members of a small team of ICT professors, the authors explain how the proposal has been implemented in the 
Barcelona School of Informatics (FIB) and the Barcelona School of Telecommunications Engineering (ETSETB), both of which figure in the top 100 of the NTU Ranking [19] in their respective fields.

The academic importance of this paper lies in presenting an innovative guide aimed at assisting engineering students to design and develop sustainable projects. The proposal is based on a tool referred to as "the Sustainability Matrix", in which cells contain questions that engineering students should take into account when undertaking their DT. The questions concern the project development, the project exploitation and the possible risks involved, three aspects in accordance with the sustainability dimensions (economic, environmental and social). The Sustainability Matrix enables students to develop sustainable projects when they graduate, as well allowing teachers to assess how sustainability is incorporated across the curriculum in the subjects they teach and in the students' DT. Section 3 describes the context in which the Sustainability Matrix has been developed and the evolution of the methodology used to assess sustainability in DT, from its initial implementation in 2012 up to the present day. It also analyzes the relationship between the Sustainable Development Goals (SDG) of the United Nations and the questions proposed in the Sustainability Matrix. Finally, the first results obtained in two schools of the UPC are presented.

\section{Related Work}

Some authors, such as [20], state that sustainability is a political quality that expands the responsibilities of engineers. In his paper, Miller analyzes the concept of sustainability and its effect on engineering practice. For this author, the perpetual nature of sustainability results in severe and perhaps unreasonable restrictions on engineering. However, most experts currently agree about the benefits of introducing sustainability awareness into higher education. The participants in the Workshop "Engineers and sustainability: achieving technological transitions" [21] were in no doubt about the capacity, motivation and the opportunity for engineers of dealing with sustainability issues.

Ciampi and Brito [22] state that engineering forms part of a new scenario in which security, infrastructure, megaprojects, sustainable development and multicultural work-teams present challenges for which they may be unprepared. In a systematic review of the literature [9] consisting of almost 250 articles on integrating sustainability into engineering curricula, one of the conclusions is that the results of this integration are in practice somewhat cursory. In this review, the issue about how faculty can be motivated to integrate sustainability into the curricula comes down to a question of future research that must be conducted. Furthermore, in a study by Sinakou et al. [23], it is shown that over 56 academics engaged in the area of education for sustainable development do not conceive the concept of sustainable development holistically, which indicates that much work remains to be done in the correct training of faculty. Moreover, sustainability in Higher-Education institutions (HEI) is becoming increasingly connected with sustainability in the private sector and with other public actors, as mentioned by Hugé et al. [24].

In the last few years, several HEI have redesigned their curricula to promote competencies related to sustainable development. As Leal Filho et al. [25] showed, the process of redesigning the curriculum has different approaches, which involve the necessity to develop changes avoiding arbitrary decisions, individual preferences or without sufficient theoretical and empirical justification. In such scenarios a question arises: how can sustainability be introduced into Higher Education curricula?

Several authors have proposed activities for introducing sustainability into the classroom in different subjects. For example, Hu et al. [26] presented a smart home test-bed based on the pedagogical model of Project-Based Learning (PBL) for undergraduate education. Clancy et al. [27] deal with sustainability by integrating an ethics case study into a first-year course lab of electrical and computer engineering. Clancy et al. [28] first describe their approach, then later enhance it in [27] by proposing the use of student surveys both prior to and on completion of their courses in order to assess the increase in their awareness of ethical issues.

Is it enough to introducing sustainability in a separate subject? Diehl et al. [29] suggest that a discussion should be conducted on the question of whether sustainability education should be 
provided separately or included as part of the regular courses. Following the integrated approach, Fleddermann [30] describes how an engineering ethics course is improved by using case studies which involve technical issues that are covered in depth during the case development. No assessment of the experience is provided, apart from the statement that the cases "sparked more interesting and informed discussion among the students than the traditional engineering ethics cases". Stables [31] goes a step further by identifying the importance of creativity and environmental sustainability on both an individual level and for the development for society as a whole. In his paper, some ideas are put forward to enhance creativity and environmental sustainability in technology education by means of an approach based on ecodesign capability. Our own experience $[32,33]$ indicates that the best way to introduce professional competencies such as communication, teamwork, ethics or sustainability is by integrating them into the curriculum, which is the way sustainability has been introduced into Higher Education curriculums in our country, as shown by the analysis of Miñano et al. [34] about the inclusion of sustainability competencies into Informatics and Industrial degrees, and Solís-Espallargas et al. [35] about their inclusion in Education degrees.

What to learn about sustainability in an engineering degree and what the best educational methodologies might be to introduce these concepts have provided the focus of studies performed by the community. For instance, Ofei-Manu and Didham [36] clearly identify significant learning factors and their related characteristics that underpin the efficacy of sustainability learning. Hedden et al. [37] developed a theoretical model with an active learning constructivist approach based on case studies. Segalàs et al. [38] have demonstrated that Lecturing Project-based, Learning Case study, Problem-based Learning, Backcasting and Role-play are the most commonly used pedagogical methodologies in sustainability education. A more recent paper by Lozano et al. [39] shows that the most common pedagogical approaches for sustainability development are: Case Studies, Interdisciplinary Team Teaching, Lecturing, Mind and Concept Maps, Project- or Problem-Based Learning, Community Service Learning, Jigsaw, Participatory Action Research and Life-Cycle Analysis.

Many efforts have been made to implement sustainable development in HEI. However, many challenges still remain, as shown in a special issue edited by Lozano et al. [40]. The 33 papers in this special issue illustrate the efforts undertaken by HEI to contribute to sustainability. These papers deal with subjects such as the introduction of sustainable development, stakeholder involvement, actions on campus, sustainability reporting and evaluation, management of organizational changes and curriculum development [41]. However, no concrete proposal is put forward regarding the introduction of sustainability into the BT and MT of Engineering Degrees, which is the focus of this present paper.

Despite all this research, Rao et al. [42] indicate the scarcity of scrupulous assessment tools to assist engineering teachers in their evaluation of the progress made in sustainability education. Most of the works found in the literature focus on the means by which sustainability may be integrated as part of a degree course, but only a few enter into details about how sustainability may be evaluated. Some of the works focus on evaluation of sustainability. For instance, Fargnoli [43] puts forward a methodical design for assessing environmental sustainability in the manufacturing industry, "in order to find the right trend to follow to pursue improvements in design activity, which take into account not only the direct environmental impact of products, but also make their development economically feasible". Specifically, the approach adopted by this author is founded on the use of the Ecodesign PILOT method as well as that of the quality function deployment for the environment. Dickinson et al. [44] propose the sustainable target method (STM), which employs both estimates of carrying capacity and economic data in order to furnish a practical sustainability target for different businesses and products: "The carrying capacity is combined with economic and life cycle inventory data to determine the relative indicator resource productivity for environmental performance and the absolute indicator eco-efficiency for sustainability". Valinejad and Rahmani [45] and Badri Ahmadi et al. [46] proposed a framework to study how sustainability analysis can be introduced in the management or selection of the supply chain. Brent and Labuschagne [47] address the lack of appropriate methods for evaluating sustainability 
from all angles regarding project and technology management. They propose a framework of criteria to assess the sustainability of engineering projects and technologies in industry. The assessment procedure proposes the application of MCDA (MultiCriteria Decision Analysis) techniques with calculated indicators. The calculation of these indicators follows environmental Life Cycle Impact Assessment (LCIA) methodologies. Other proposals, such as that by Yonaidi and Boosroh [48], approach the matter from a multi-criteria perspective they refer to as the Sustainability Assessment Method (SAM), which they employ to evaluate and classify the sustainability of diverse types of power plants running on different types of fuel. Kant et al. [12] present a methodology to quantify the environmental footprint through the life-cycle assessment. Feki and Chabchoub [49] advocate the "ecological footprint" as a good tool for developing and evaluating processes for the estimation and improvement of the environmental performance of supply chains in Tunisia. Rahman et al. [50] adopt the approach of a Sustainability-driven Information System Audit (SISA) integrating the Analytical Hierarchy Process (AHP) and the Fuzzy Set Theory (FST), with the aim of determining the sustainability performance in Information Systems (IS), centered on public organization. Sustainability consists of the following five audit criteria dimensions: economic, environmental, resources, social and technology, in which the AHP identifies the pertinence of the sustainability dimensions and is related to attributes in order for the relevant audit areas to be prioritized. This proposal is orthogonal to the one presented in this paper, although it uses different dimensions.

Our proposal consists of a tool to help students to introduce and assess sustainability in their DTT. Unlike the papers referenced in this section, which deal with tools that are largely focused on solving specific problems, the tool presented herein is a generalist tool that can be used in any engineering project. The proposal set out in this paper is in line with the guidelines that mark the European law (Directive 2014/95/EU of the European Parliament and of the Council of 22 October 2014 [4]) and the standards proposed by GRI [6] for companies, as an analysis of resources and direct and indirect impacts performed at the environmental, social and economic level.

As Hugé et al. [24] state: "The commitment of a small team of 'sustainability champions' is a key factor for success, as it is at least a tacit support from the institution's hierarchy".

\section{Materials and Methods}

This section describes the context in which the Sustainability Matrix has been developed and the evolution of the methodology used to assess sustainability in DT, from its initial implementation in 2012 and up to the present day. The research approach is based on the action research methodology, with qualitative analysis of the results. In a first stage, the authors drew up a state of the art on the basis of a documentary search. This initial approach gave rise to a tool that is described in Section 3.2. The results from the first years during which this tool was applied were the object of a qualitative analysis of the students' own sustainability reports, which turned out to be quite different from what had been expected. In a second iteration, the problems identified were also analyzed and a second documentary search for tools capable of solving these problems was conducted, which resulted in the proposal of the Sustainability Matrix (Sections 3.3 and 3.4). The initial results of this new proposal are presented in Section 3.4 and are based on a qualitative analysis of the sustainability reports drawn up in accordance with the new tool. In addition to the sustainability reports, the opinions of students and teachers, expressed in focus groups organized for that purpose, have also been taken into account in order to define the improvement process.

\subsection{The Context}

In 2008, the UPC decided to incorporate sustainability competency into the curricula of all degrees. In 2010, the Informatics (FIB) and the Telecommunications (ETSETB) new degree curricula, adapted to the EHEA, got under way. One of the objectives of the new degrees was the integration of sustainability into different subjects across the curriculum. Some examples of how these schools deal with sustainability within the different subjects are presented in Sanchez et al. [51]. As of the 
present day, sustainability competency has been successfully introduced throughout the curriculum of both degrees.

While it is essential to develop the concept of sustainability across all the subjects belonging to the curriculum, we nevertheless agree with other authors [52] in the view that DT provides the best opportunity for practicing and assessing professional competencies such as sustainability.

The Bachelor's Thesis (BT) is a major element in a bachelor degree of any engineering discipline. BT gives students an opportunity to use and implement methods, techniques and tools they have studied throughout the Degree. However, students require clear guidelines in order to complete their BT. A study of 172 projects, conducted over 10 years in an industrial engineering and management department, concluded that a methodology to achieve the aim and objectives of the BT is needed [53]. The study presents an assessment process to ensure professional performance.

Furthermore, the IEEE/ACM Computing Curricula recommendations [54] propose the use of projects or case studies to ensure that students can successfully apply the knowledge they have acquired, and by doing so enable them to interweave both content and skills. However, in the absence of the appropriate guidelines, students will be confined to the evaluation of the sustainability of their work and will not take the sustainability of the project as a whole or its subsequent impact into account. The authors are of the opinion that students should contemplate projects in their entirety, with a realization of the significant impact on both the environment and society that some decisions may have.

Based on this idea, the FIB decided that every BT must include a Sustainability Report, and the ETSETB for its part decided that all projects developed for students in the Advanced Engineering Project subject (a capstone course in the fourth year) should also include a Sustainability Report. Both sustainability reports follow the guidelines described in this paper. In the case of the FIB, the Sustainability Report consists of a chapter of the BT report, the document in which students describe the work developed in the BT. To guide the student in the writing of the Sustainability Report, the authors decided to follow the Socratic Methodology [55], and consequently formulated a series of questions to make students consider carefully the sustainability implications of their BT. This immediately gave rise to a new problem: How could the questions be formulated in such a way as to encourage students to think about the implications of their work in-depth? The authors opted for the use of a matrix structure to organize these questions, that is, the Sustainability Matrix. Although the Sustainability Matrix was initially designed only to help students in their BT, the matrix was completed with some additional questions. These questions are too deep to be included in a BT, but should be considered in a Master's Thesis or in any engineering project.

\subsection{Principles and Problems in Previous Proposal}

The principles on which the Sustainability-Report writing is based have changed with the experience and praxis, as will be explained in Section 3.3. Initially, the authors were of the opinion that the composition of the Sustainability Report should revolve around:

- Awareness of the importance of sustainability: the intention was not to force students to produce a sustainable BT, but rather that they should be aware of the level of sustainability of their project.

- Open questions: the students should not be obliged to fill out a specific questionnaire that limited their freedom and was probably not well-adapted to their BT. Instead, through a series of open questions, they are invited to globally reflect about the sustainability of their project.

- A matrix to classify the questions: The questions were classified by using a matrix, the format of which was aimed at clarifying the structure and objectives of the Sustainability Report. In the first implementation, the dimensions of sustainability were arranged in the columns of the matrix and some aspects related to the project (planning, results and risks) in the rows. This approach was presented at the Frontiers in Education Conference by López et al. [56]. The proposal was based on the fact that the most important decisions for the project were taken in the Planning phase. Therefore, all (or almost all) the matrix questions had to arise in the Planning phase. The Results row was to be used to assess whether the project objectives had been achieved. Finally, the Risks 
row contained questions designed to help students to think about scenarios that could arise and jeopardize their project, in a similar way to Directive 2014/95/EU of the European Parliament and of the Council of 22 October 2014 [4], which specifies that the main risks involved in the activity carried out by a company must be reported.

- Quantitative assessment, i.e., measuring the level of sustainability of the BT. Initially, in order to evaluate the sustainability of their projects, it was regarded as appropriate to ask the students to quantify the sustainability of each cell in the matrix according to their own answers to the questions, the aim being for students to be able to estimate quantitatively the degree of sustainability of the project. This idea was inspired by Felber's Matrix for the Common Good [57]. The Matrix for the Common Good is aimed at evaluating the commitment of an enterprise to the common good. The columns in the Common Good Matrix correspond to common values found in the constitutions of many countries, such as human dignity or social justice. The rows contain the stakeholders, all of whom are players affected by the activity of the company evaluated, i.e., employers, customers, etc.

Students began to present the first BTs at the FIB during the 2012-13 course, but it quickly became clear that the sustainability reports they were presenting differed quite substantially from what was expected. What was happening?

Three problems were identified:

(1) Overestimation of the level of sustainability awareness of students and teachers.

(2) The proposal was too open

(3) Difficulties in quantifying sustainability. Is a bachelor's student able to quantify sustainability?

The following sections present the Sustainability Matrix, the instrument proposed in this paper, and a proposal for how the three problems identified can be solved.

\subsection{The Proposed Instrument: the Sustainability Matrix}

In the author's previous approach [56], while the matrix rows contained some aspects of the project (planning, results and risks), that proposal did not take into consideration the assessment of the project's exploitation or the effect of dismantling, since the results referring to those aspects are observed at the end of the project scope, which in many cases ends before the implementation phase. Thus, when defining the new proposal presented in this paper, the authors decided to maintain the matrix structure of three columns and three rows, but changing the classification of Planning-Results-Risks in rows to a system that covers the following project features.

- The Project Development, which should address planning, introduction and execution.

- The Project Exploitation, which begins after the implantation phase and ends with project dismantling.

- The Risks intrinsic to the project itself vis-à-vis its construction, lifespan and dismantling.

Finally, rows and columns were swapped for the sake of clarity (columns show the timeline of a project better than rows)

Table 1 shows a general view of the Sustainability Matrix and the meaning of each cell.

Table 1. Meaning of cells in the Sustainability Matrix.

\begin{tabular}{cccc}
\hline & Project Development & Project Exploitation & Project Risks \\
\hline Environmental & Consumption design & Ecological footprint & Environmental risks \\
Economic & Project bill & Viability plan & Economic risks \\
Social & Personal impact & Social impact & Social risks \\
\hline
\end{tabular}

The meaning of each cell in the Sustainability Matrix in Table 1 is as follows: 
- Environmental/Project Development cell: The impact of the execution of the project on the environment (waste generation and energy consumption). It can be measured, for example, in greenhouse emissions (C02 equivalent emissions).

- Environmental/Exploitation cell: The environmental footprint of the project during its lifespan. It can be measured with the same parameters as the previous cell.

- Environmental/Risks cell: Represents the set of eventualities that may make the environmental impact of the project more negative than foreseen.

- Economic/Project Development cell: The project bill, the cost of the resources (materials and human resources) arising from its planning, design, introduction and execution.

- Economic/Exploitation cell: The project viability plan.

- Economic/Risks cell: The economic risks that may cause the costs initially estimated for the project to vary.

- Social/Project Development cell: The impact of the project on the people who developed it.

- Social/Exploitation cell: The impact of the project on the collectives affected either directly or indirectly.

- Social/Risks cell: Any eventuality that may make the social impact of the project on any of the groups related to it more negative than expected.

The Sustainability Matrix has the following features:

- The matrix will serve both as a guide to writing the Sustainability Report and also as a tool for assessing the sustainability of the project.

- The cells of the matrix contain questions, in accordance with the Socratic Methodology.

- Students should use the matrix questions to conduct a sustainability analysis throughout the whole development of the project.

The scope of a BT is usually restricted to the Project Development column, as it is an academic exercise. A real engineering project could be completed in this phase and the exploitation could start in the second column of the Sustainability Matrix. However, a DT project may form only a part of an engineering project or even a project that does not reach its implementation phase.

The valuations carried out during the project scope are "measurable", while the valuations reached after the scope can only be estimated in the Sustainability Report. The risks are obviously unpredictable, unless the probability of occurrence is known. For this reason, the column corresponding to Project Development contains measurable ratings, while in the Exploitation (and risks, when possible) the ratings are always estimated, as shown in Table 2.

Table 2. Measurable vs. estimable aspects of an engineering project.

\begin{tabular}{cccc}
\hline & Project Development & Project Exploitation & Project Risks \\
\hline $\begin{array}{c}\text { Environmental } \\
\text { Economic } \\
\text { Social }\end{array}$ & Measurable & Estimable & Unpredictable \\
\hline
\end{tabular}

The Sustainability Matrix presented in this paper is intended for engineering projects, but may easily be adapted to other degrees by slightly adapting some questions.

Tables 3 and 4 show the list of questions proposed for the Sustainability Matrix of a BT (Table 3) and an MT (Table 4). These questions have been selected from an extensive bibliographic review on the evaluation of engineering projects. The rows labeled as " $\mathrm{I}$ " correspond to the questions that should be addressed in the project-planning phase (Initially). Rows labeled as " $\mathrm{F}$ " contain the questions that should be addressed during the project-implementation phase (and presented in the Final Report of the project). In Table 4, an additional row P (Professional) contains questions that should be considered in a MT or in a real engineering project, but not in a BT. Questions in both tables are numbered with a 
code to simplify the tables, and the list of questions can be found below the tables. This code will be also used when the questions will be linked to the learning outcomes of the SDGs in Section 4.

Table 3. Questions in the Sustainability Matrix for a Bachelor's Thesis.

\begin{tabular}{ccccc}
\hline & & Project Development & Project Exploitation & Project Risks \\
\hline \multirow{2}{*}{ Environmental } & I & I1.1.1. & I1.2.1. & \\
& F & F1.1.2., F1.1.3. & F1.2.2., F1.2.3. & F1.3.1. \\
Economic & I & I2.1.1. & I2.2.1. & F2.3.1. \\
Social & F & F2.1.2., F2.1.3. & F2.2.2., F2,2,3. & \\
& I & I3.1.1. & I3.2.1., I3.2.2. & F3.3.1., F3.3.2. \\
\hline
\end{tabular}

Table 4. Questions in the Sustainability Matrix for a Master's Thesis.

\begin{tabular}{ccccc}
\hline & & Project Development & Project Exploitation & Project Risks \\
\hline \multirow{3}{*}{ Environmental } & I & I1.1.1. & I1.2.1. & \\
& P & F1.1.2., F1.1.3. & F1.2.2., F1.2.3. & F1.3.1. \\
& I & P1.1.4., P1.1.5. & P1.2.4., P1.2.5., P1.2.6. & P1.3.2. \\
Economic & F & F2.1.2., F2.1.3. & I2.2.1. & \\
& P & P2.1.4. & P2.2.4., P2.2.5., F2,2,3. P2.2.6., P2.2.7. & P2.3.1. \\
Social & I & I3.1.1. & I3.2.1., I3.2.2. & \\
& F & F3.1.2. & F3.2.3., F3.2.4. & F3.3.1., F3.3.2. \\
\hline
\end{tabular}

Below the reader can find the list of questions:

\section{Environmental}

- I1.1.1. Have you estimated the environmental impact of the project? Have you considered how to minimize the impact, for example, by reusing resources?

- $\quad$ I1.2.1. How is the problem you want to address currently being solved (state of the art)? How will your solution environmentally improve current solutions?

- F1.1.2. Have you quantified the environmental impact of the project? What steps have you taken to reduce the impact? Have you quantified this reduction?

- F1.1.3. If you did the project again, could it be done with fewer resources?

- F1.2.2. What resources do you estimate will be used during the lifetime of the project? What will be the environmental impact of these resources?

- F1.2.3. Will the project reduce the use of other resources? Overall, will the use of the project improve or worsen the ecological footprint?

- F1.3.1. Could any scenarios arise that might increase the footprint of the project?

- P1.1.4. What is the origin of the raw materials and/or materials used?

- P1.1.5. Have you taken into account dismantling once the project comes to an end? If the project is a product, what criteria to facilitate subsequent recycling have been taken into account in the design?

- P1.2.4. Have you planned a way to measure the environmental impact of the project? Will a follow-up of the environmental impact be performed?

- P1.2.5. When the life of the project comes to an end, what waste is generated? Can the environmental impact of dismantling be reduced?

- P1.2.6. Could the project be carried out so that the environmental impact is less?

- P1.3.2. Can the impact of possible scenarios that might increase the footprint of the project be prevented or mitigated? 


\section{Economic}

- $\quad$ 22.1.1. Have you estimated the cost of the project (human and material resources)?

- I2.2.1. How is the problem you want to address currently being solved (state of the art)? What could economically improve your solution as regards current solutions?

- F2.1.2. Have you quantified the cost (human and material resources) of the project? What decisions have you taken to reduce the cost? Have you quantified the savings?

- F2.1.3. Is the estimated cost similar to the final cost? Have you justified the differences (lessons learned)?

- F2.2.2. What is the estimated cost of the project over its lifetime? Could this cost be reduced to make the project more feasible?

- F2.2.3. Have you taken into account the cost of adjustments/updates/repairs over the lifespan of the project?

- F2.3.1. Could any scenarios arise that may jeopardize the viability of the project?

- $\quad$ P2.1.4. Will the initial investment of the project make it competitive?

- P2.2.4. Have you planned some means of measuring the economic impact of the project? Will a follow-up of this impact be carried out?

- P2.2.5. Have you drawn up a viability plan of the project?

- P2.2.6. Would the dismantling of the project incur any additional costs?

- P2.2.7. Could any other project benefit from the results of this one?

- P2.3.2. Could we prevent or mitigate the impact of possible scenarios that might undermine the viability of the project?

\section{Social}

- $\quad$ I3.1.1. What do you think the realization of this project will bring to you personally?

- I3.2.1. How is the problem you want to address currently being solved (state of the art)? What could socially improve (quality of life) your solution as regards previous ones?

- $\quad$ I3.2.2. Is there a real need for the project?

- F3.1.2. Does this project involve significant reflections on the personal, professional or ethical standards of the people working in the project?

- F3.2.3. Who benefits from the use of the project? Is there any group that may be adversely affected by the project? If so, to what extent?

- $\quad$ F3.2.4. To what extent does the project solve the problem initially raised?

- F3.3.1. Could any scenarios arise to make the project detrimental to any particular segment of the population?

- F3.3.2. Could the project create any kind of dependency that might leave users in a weak position?

- P3.1.3. What is the social and political situation in the country/place/city/... where the project is being implemented? What is the current situation of the sector related to the project?

- P3.1.4. Is the origin, development and/or manufacture of materials ethical (working conditions, occupational hazards, etc.)? And is the logging company, manufacturer or distributor ethical?

- P3.2.5. Have you planned any way of measuring the social impact of the project? Will a follow-up of this impact be conducted?

- P3.2.6. How will the dismantling of the project impact groups involved in it?

- P3.2.7. Could you carry out the project so that it increases its positive social impact?

- $\quad$ P3.2.8. Does the project have any advantages or disadvantages for the situation of/country/city industry...?

- P3.3.3. Could we prevent or mitigate the impact of possible scenarios that could harm any social group directly or indirectly related to the project? 


\subsection{Facing the Problems Detected}

\subsubsection{First Problem: Overestimation of the Level of Sustainability Awareness of Students and Teachers}

As stated in Section 3.2, one of the reasons why the students were unable to write a good Sustainability Report of their DT was because their competency level in sustainability was overestimated (Factor 1).

We should accept that it is not an easy task to raise engineering students' awareness of sustainability, nor can immediate results be obtained. It requires persistence and must be highly transversal; above all, it is also a long-term project. As we have been able to verify, it is not enough to develop good and precise guides. A pedagogical strategy that promotes activities and facilitates communication is essential to obtain the full engagement of the teaching staff and students.

In order to solve this problem, it is necessary to improve communication with students and to adopt a good pedagogical approach to sustainability. Teachers must be able to transmit directly and effectively the importance of taking sustainability into account in any engineering project, as well as explaining clearly how to prepare a DT Sustainability-Report.

In order to provide support for teachers and students, the authors recorded a short, simple, explicit video explaining the relevance of considering sustainability in engineering projects, and illustrating the main aspects when writing a Sustainability Report. The video (https://www.youtube.com/playlist? list=PLkgord6_YlwRMC8It6gNJTO96cknfx1P1) is divided into four independent sections that can be viewed separately. The first section is an introduction and explains why sustainability must be considered in an engineering project, starting from the Planning phase. It outlines basic concepts on sustainability and explains how the Sustainability Report should be organized. Finally, it briefly describes the Sustainability Matrix. Each of the other three videos describes the questions that students must address in their DT for each of the sustainability dimensions. In total, the four videos last less than ten minutes. These videos contribute to resolving Factor 1 (overestimation of the level of sustainability awareness of students and teachers) presented in Section 3.2.

Some years ago, when this work first started, the authors believed that students should address the sustainability of their projects holistically rather than by analyzing individually each of the three dimensions of sustainability (environmental, social and economic). However, a pilot experience demonstrated that undergraduate students (and most current engineers) do not possess sufficient skills in sustainability to tackle a holistic approach. Students usually work with the three sustainability dimensions separately during their studies, and they find it more natural to analyze them individually. Students would probably adopt a fully holistic approach after completing more projects and having acquired greater experience, although the authors found that, when students are faced with their DT, which was not the case. Consequently, it was finally decided to analyze the sustainability dimensions of the DT separately. This decision is also supported by both the European law (Directive 2014/95/EU of the European Parliament and of the Council of 22 October 2014, [4]), and the GRI standards [6] that address the three dimensions of sustainability separately.

\subsubsection{Second Problem: A Too Open Proposal}

Regarding Factor 2, it appears that the first Sustainability Report proposal was too open, and consequently instead of guiding the students, it confused them. The authors explicitly avoided specifying a single model for the DT, precisely so as not to restrict the wide variety of possible DT. However, for human beings, imitation is one of the basic ways of learning. It seems that students were unable to create their own report without having a reference model. The problem could be due to a lack of culture on sustainability or to an insufficient experience in writing sustainability reports, both on the part of the students and on that of their teachers.

In this proposal, although the questions are organized in a matrix, students are required to answer all of them one by one. This is one of the main differences in the writing of the Sustainability Report compared to the previous proposal, in which the students were obliged to write the Sustainability 
Report holistically, based on the global reflections made on all the questions in the matrix. In the present proposal, the student must answer all the questions sequentially because they have been trained in this way in the different subjects that develop the sustainability competency. The classification of the questions in the matrix helps the students to understand at what stage of the project each question should be addressed, and to which dimension of sustainability each question corresponds, in a similar way to how GRI organizes the different topics to be evaluated in the reports of the companies in different standards. This proposal resolves Factor 2 (a proposal that is too open-ended), as raised in Section 3.2.

It is recommended that students answer the questions sequentially by reading the Sustainability Matrix in a horizontal order. That is, in the project they are required to analyze separately each of the sustainability dimensions, in accordance with the following order for each dimension: Project Development - Exploitation - Risks. In this way, students find it easier to think of the dimensions separately. The answers to the Sustainability Matrix questions should be reasoned, i.e., not just a cell valuation or a yes/no answer is expected. More important than answering the questions is the process of thinking, reflecting and researching that will stem from these questions.

With the experience acquired from conducting many projects, the authors believe that over time the students will be able to think holistically about project sustainability.

3.4.3. Third Problem: Difficulties in Quantifying Sustainability. Is a Bachelor Student Able to Quantify Sustainability?

With regard to Problem 3 (difficulties in quantifying sustainability), one of the problems that students found when preparing their sustainability reports was identifying good indicators of sustainability. In the initial proposal, students were advised to evaluate each of the cells in the matrix numerically, as in Felber's Matrix for the Common Good [57], but no clear indicators were provided. Students were required to conduct that evaluation by defining their own indicators, although apparently they lacked both the capacity and the experience to do so. However, what is worse, in most cases their project supervisor also lacked these abilities.

Unfortunately, a set of sustainability indicators useful for all types of projects does not exist [1]. However, some organizations have proposed tools for selecting indicators. For example, in Sustainable Measures [58] a series of requirements is presented in which the sustainability indicators required by a community are set out. Regretfully, this method is difficult to extrapolate to an engineering DT.

The United Nations platform for sustainable development [2] proposes a series of sustainability indicators grouped into the 17 SDGs:

- Goal 1: End poverty in all its forms

- Goal 2: Zero hunger

- Goal 3: Health

- Goal 4: Education

- Goal 5: Gender equality and women's empowerment

- Goal 6: Water and sanitation

- Goal 7: Energy

- Goal 8: Economic growth

- Goal 9: Infrastructure, industrialization

- Goal 10: Inequality

- Goal 11: Cities

- Goal 12: Sustainable consumption and production

- Goal 13: Climate change

- Goal 14: Oceans

- Goal 15: Biodiversity, forests, desertification

- Goal 16: Peace, justice and strong institutions 
- Goal 17: Partnerships

Initially, a set of indicators was chosen for each goal. However, casuistry is huge, and the choice of suitable indicators strongly depends on the nature of the project. Evaluating these indicators numerically is not an easy task. Some indicators (for example, energy consumption) are easy to quantify, while others (such as the impact of the project on the digital divide) can only be quantified subjectively. Although the framework of indicators proposed by the United Nations is complete and widely accepted by the global community, it does not provide metrics for easily quantifying sustainability on the basis of a set of indicators.

Assessing a numerical qualification for the sustainability of their DT is beyond the knowledge and the experience of students. Consequently, given the difficulty of quantifying the sustainability of their DT objectively, and the lack of clear indicators to do so, together with the discomfort experienced by a significant group of teachers, the authors decided to remove the quantification requirement for each matrix cell until an adequate methodology that enables an objective assessment becomes available.

\section{Preliminary Results and Discussion}

\subsection{Identifying the SDG in the Sustainability Matrix}

In 2017, UNESCO published the document entitled "Education for Sustainable Development Goals: learning objectives" [3], in which 15 learning objectives for each of the 17 SDGs are identified. In total, the document describes 255 learning objectives. The learning objectives are classified into three categories: Cognitive (C), Socio-Emotional (SE) and Behavioral (B). Each category contains five learning objectives, which in this paper have been numbered C1..C5 for Cognitive ones, SE1..SE5 for Socio-Emotional and B1..B5 for Behavioral ones.

We have analyzed the relationship between the learning objectives proposed by UNESCO and the questions proposed in the Sustainability Matrix. This relationship identifies which of the SDG learning objectives would be developed during the DT. Figure 1 presents the relationship between the questions in the proposed matrix and the learning objectives of each SDG.

Figure 1 shows the sustainability matrix questions in the rows, classified according sustainability dimensions, and the SDGs in the columns. Each cell contains the learning objectives of each SDG that have been identified for the corresponding question in the matrix. Some interesting conclusions can be drawn from the figure:

- Four SDGs are not directly developed during the DT of engineering degrees. These SDGs have been highlighted in red (2-Zero hunger, 6-Water and sanitation, 14-Oceans and 15-Biodiversity, forests, desertification).

- Questions referring to the Economic dimension (area shaded in gray) are related to fewer SDGs than questions referring to the Social and Environmental dimensions. Figure 1 shows that only SDGs 8 (Economic growth), 9 (Infrastructure, industrialization) and 12 (Sustainable consumption and production) are related to questions corresponding to the Economic dimension.

- Three SDGs are related to questions corresponding to the 3 dimensions of sustainability (8-Economic growth, 9-Infrastructure and industrialization, and 12-Sustainable consumption and production), and three other SDGs are related to questions from both the Social and Environmental dimensions (11, 13 and 17). The other seven SDGs are related only to questions corresponding to one of the Social or Environmental dimensions. One SDGs is related only to questions corresponding to the Environmental dimension (7-Energy), while the other six are related only to questions from the Social dimension (1-End poverty in all its forms, 3-Health, 4-Education, 5-Gender equality and women's empowerment, 10-Inequality, and 16-Peace, justice and strong institutions).

The fact that only three SDGs are related to economic questions is reasonable, since the learning objectives arise mainly from the Social and Environmental dimensions of sustainability. It is also 
reasonable that some learning objectives relate only to one of these dimensions (Social or Environmental) due to the very nature of the SDG. As a conclusion, the questions corresponding to the Economic dimension are related to only three SDG, while those of the Social dimension are related to twelve and those of the Environmental dimension to seven. From these data it could be deduced that the questions of the Sustainability Matrices are more focused on the Social dimension, but what actually happens is that the SDGs themselves are more focused on social rather than on environmental aspects, and much more focused on these two dimensions than on the Economic dimension of sustainability. This fact is clearly reflected in Figure 1.

\begin{tabular}{|c|c|c|c|c|c|c|c|c|c|c|c|c|c|c|c|}
\hline & Question & & & & & & & & SDG & & & & & & \\
\hline & & 1 & 3 & 4 & 56 & 7 & 8 & 9 & 10 & 11 & 12 & 13 & \begin{tabular}{|l|l|}
14 & 15 \\
\end{tabular} & 16 & 17 \\
\hline & I1.1.1. & & & & & B2 & B5 & & & B5 & C4, C5 & B5 & & & B1 \\
\hline & F1.1.2. & & & & & B2 & & B2 & & B5 & B1 & B1 & & & SE3 \\
\hline & F1.1.3. & & & & & B2 & B5 & B2 & & B5 & B1 & B1, B5 & & & B1, SE3 \\
\hline & P1.1.4. & & & & & & & & & & & & & & \\
\hline 艺 & P1.1.5. & & & & & B2 & & B2 & & B5 & B1 & B1 & & & SE3 \\
\hline$\Phi$ & I1.2.1. & & & & & B2 & & B1, C4 & & & & & & & \\
\hline$\frac{\varepsilon}{\varrho}$ & F1.2.2. & & & & & B2, C3 & & $\begin{array}{l}\text { B2, C2, } \\
\text { C3, C4 }\end{array}$ & & B5 & \begin{tabular}{|c|} 
B1, B4, \\
C5
\end{tabular} & B1 & & & \\
\hline.$=$ & F1.2.3. & & & & & B2 & B5 & B2 & & B5 & B1 & B1,B5 & & & B1, SE3 \\
\hline$\gtrsim$ & P1.2.4. & & & & & B2 & B1 & B2 & & B5 & B1 & B1 & & & \\
\hline & P1.2.5. & & & & & B2 & B5 & B2 & & B5 & B1 & B1, B5 & & & B1, SE3 \\
\hline & P1.2.6. & & & & & B2 & B5 & & & & & B5 & & & B1 \\
\hline & F1.3.1. & & & & & & & & & B5 & B1 & B1 & & & SE3 \\
\hline & P1.3.2. & & & & & B2 & B5 & & & B5 & B1 & B1, B5 & & & B1, SE3 \\
\hline & I2.1.1. & & & & & & B4 & & & & & & & & \\
\hline & F2.1.2. & & & & & & B4 & & & & & & & & \\
\hline & F2.1.3. & & & & & & B4 & & & & & & & & \\
\hline & P2.1.4. & & & & & & & $\mathrm{C5}$ & & & $\mathrm{C} 5$ & & & & \\
\hline & 12.2.1. & & & & & & & B1, C4 & & & & & & & \\
\hline 을 & F2.2.2. & & & & & & B4 & & & & C4, C5 & & & & \\
\hline ह & F2.2.3. & & & & & & B4 & & & & C4, C5 & & & & \\
\hline ธ & P2.2.4. & & & & & & B1 & $\begin{array}{l}\text { B2, C2, } \\
\text { C3, C4 }\end{array}$ & & & B4, C5 & & & & \\
\hline Ш & P2.2.5. & & & & & & B4 & & & & & & & & \\
\hline & P2.2.6. & & & & & & B4 & & & & & & & & \\
\hline & P2.2.7. & & & & & & & $\begin{array}{l}\mathrm{B} 2, \mathrm{C} 2, \\
\mathrm{C} 3, \mathrm{C} 4\end{array}$ & & & B4, C5 & & & & \\
\hline & F2.3.1. & & & & & & B4 & & & & & & & & \\
\hline & P2.3.2. & & & & & & B4 & & & & & & & & \\
\hline & I3.1.1. & SE5 & & & & & & B2 & & & $\mathrm{C} 5$ & B1 & & & \\
\hline & F3.1.2. & SE5 & & & C5 & & & $\begin{array}{c}\text { B2, C1, } \\
\text { C2 } \\
\end{array}$ & $\begin{array}{c}\text { C2, SE1, } \\
\text { SE5 }\end{array}$ & & C5 & B1 & & $\begin{array}{c}\text { C4,C5, } \\
\text { SE4 }\end{array}$ & \\
\hline & P3.1.3. & $\mathrm{C} 4$ & C1 & C3 & $\mathrm{C5}$ & & & C3 & C1, C4 & & $\mathrm{C} 2$ & & & & \\
\hline & P3.1.4. & B1, B5 & & & B2 & & B1, B5 & B1, B3 & B4 & B1, B4 & B1, B4 & B5 & & & B1, SE3 \\
\hline & |3.2.1. & & & & B2 & & & B1, C4 & $\begin{array}{c}\text { B2, B3, } \\
\text { B4 }\end{array}$ & & & & & & \\
\hline $\bar{\sigma}$ & 13.2.2. & & & & & & & $\mathrm{C} 2$ & B1 & & & & & SE4 & \\
\hline$\overline{0}$ & F3.2.3. & & & & & & & $\mathrm{C} 2$ & B1 & & & & & SE4 & \\
\hline ஸ & F3.2.4. & & & & & & B1 & & & & & & & & \\
\hline & P3.2.5. & & & & B2 & & B1 & & B2, B4 & & & & & & \\
\hline & P3.2.6. & & & & & & B1 & C1 & & & & & & & \\
\hline & P3.2.7. & $\mathrm{B} 1, \mathrm{~B} 5$ & & & B2 & & $\mathrm{B} 1, \mathrm{~B} 5$ & & B2, B4 & B1, B4 & B1 & B5 & & & B1, SE3 \\
\hline & P3.2.8. & & & & B2 & & & & B2, B4 & & & & & & \\
\hline & F3.3.1. & B1, B5 & & & B2 & & B1, B5 & & B4 & & B1 & & & & SE3 \\
\hline & F3.3.2. & & & & B2 & & & & B2, B4 & & & & & & \\
\hline & P3.3.3. & B1, B5 & & & B2 & & $\mathrm{B} 1, \mathrm{~B} 5$ & & B4 & B1, B4 & B1 & B5 & & & $\mathrm{B} 1, \mathrm{SE} 3$ \\
\hline
\end{tabular}

Figure 1. Relationship between the questions of the Sustainability Matrices of the Bachelor's and Master's Theses and the learning objectives of each Sustainable Development Goals (SDG). 


\subsection{Preliminary Results}

The curriculum of the FIB Bachelor's Degree in Informatics Engineering includes a compulsory semi-virtual Project Management subject, which all students are required to study while doing their BT. Cooperation, complicity and interaction with the coordinators and teachers of this subject are key for students to write a good Sustainability Report. In this subject, students reinforce their knowledge of team and project management. The sustainability of engineering projects is one of the topics they develop, which they do using the Sustainability Matrix. Students start their BT while they are studying the course, and apply all the work they do towards their BT. At the end of the course, they write a report with the work they have developed, which serves as an embryo of the BT report. This report includes an initial version of the Sustainability Report, which includes the sustainability analysis carried out during the planning stages of the project. More details about this subject can be found in [59]. Unfortunately, FIB students are still presenting the first BTs undertaken according to the methodology proposed in this paper for this course, so no results are available yet.

At the ETSETB, students are required to write a Sustainability Report on the projects undertaken in three subjects:

- One compulsory subject in the Bachelor's Degree in Telecommunications Engineering: Advanced Engineering Project (AEP)

- One compulsory subject in the Master's Degree in Telecommunications Engineering: Management of Telecommunication Projects (MTP).

- One compulsory subject in the Master's in Advanced Telecommunication Technologies: Entrepreneurship for the World Challenges (EWOC).

In all subjects, the same teacher explains how the Sustainability Report should be implemented according to the methodology proposed in this paper, and guides its development through the different projects undertaken by the students.

The teacher explains what professionals and ICT companies are doing to take into account and report on sustainability in their projects. The explanation begins with the references to the deontological codes of the professional associations in the ICT area (https://www.enginyeriainformatica. cat/wp-content/uploads/2009/07/codigo-deontologico-coeinf-12-esp.pdf, https:/www.coit.es/system/ files/codigo_deontologico_2016.pdf) and to the European Directive 2014/95/EU of October 22, 2014 (https:/eurresidues/eli/dir/2014/95/oj) on disclosure of non-financial information, and its transposition into Spanish Law 11/2018 of December 28 (https://www.boe.es/boe/dias/2018/12/29/pdfs/BOE-A-201817989.pdf) regarding non-financial information and diversity.

After this context regarding laws and regulations, the teacher explains how the Global Reporting Initiative (GRI, https://www.globalreporting.org/standards) standards work, since these are the sustainability reports most commonly used by large companies (https://database.globalreporting.org/), and analyzes an example in depth. Next, the teacher sets out the main social and environmental implications of the complete life cycle of ICT applications, and presents the Sustainability Matrix as a concise version of these regulations and standards adapted to the academic year. The teacher also makes it clear that the assessment of the subject will not take into account the level of sustainability of the project carried out, but rather the quality of the report that the students write based on the Sustainability Matrix (for example, if students have accounted very well for emissions of $\mathrm{CO}_{2}$ eq, even though they may not have designed the project with the aim of reducing emissions).

In the EWOC and AEP subjects, students form groups, each group undertaking a different project, while at MTP all the groups undertake the same project.

- At AEP, each group of students carries out a project based on a challenge set by a company (some projects have confidentiality agreements) or an NGO. The project does not end with a completely finished product, but it does end with a minimally functional MVP (Minimum Viable Product). 
- At EWOC, students propose a project theoretically. They decide on the project within the context set by the teacher, which last semester consisted of a climate emergency in the city of Barcelona. The end result of their work is a Pitch Deck aimed at convincing potential investors.

- At MTP, the project consists in building a wireless communication device, which they test through competitions between the groups themselves on campus.

In the second semester of the 2019-2020 academic year, the AEP subject had 10 groups of students, EWOC had 8 groups and MTP had four. In total, 22 projects were carried out involving 179 students, according to the distribution shown in Table 5. Of the total of 22 projects, 17 projects presented a full report and 5 did not. In terms of students, 147 students belonged to a group that presented a complete report, with all the questions on the Sustainability Matrix answered, which represents $82 \%$ of the total number of students involved.

Table 5. Distribution of projects and students in the three subjects, and quantity and percentage of completion of the report.

\begin{tabular}{ccccc}
\hline Subject & Project & Student & $\begin{array}{c}\text { Complete Reports } \\
\text { (Number and } \\
\text { Percentage) }\end{array}$ & $\begin{array}{c}\text { Students Who Have Participated } \\
\text { in a Group Submitting a Complete } \\
\text { Report (Number and Percentage) }\end{array}$ \\
\hline AEP & 10 & 101 & $9(90 \%)$ & $90(90 \%)$ \\
EWOC & 8 & 42 & $5(62 \%)$ & $30(71 \%)$ \\
MTP & 4 & 36 & $3(75 \%)$ & $27(75 \%)$ \\
Total & 22 & 179 & $17(77 \%)$ & $147(82 \%)$ \\
\hline
\end{tabular}

Among the groups that answered all the questions, three did so excellently and presented more data than requested (two groups at EWOC and one group at AEP), and three others did so minimally, using monosyllables in many cases and without providing many explanations (one group in MTP and two groups in AEP).

Table 6 presents a summary of the results from the evaluation of the reports submitted. The rows show the set of indicators used to evaluate the reports, while the columns show the number of reports that have obtained each level of evaluation (excellent, good, poor or unacceptable/no). The column labeled Unacceptable/no contains the number of projects that have been evaluated as "unacceptable" for a given indicator, or when the response to the indicator is simply "no" (for example, for the indicator "Does the team answer all the questions?"). In the MTP course, the last three concepts of the table have not been included in the rubric.

Table 6. Indicators used to evaluate in the rubric, and number of reports that have reached each level of evaluation.

\begin{tabular}{|c|c|c|c|c|}
\hline Indicators for All Subjects & Excellent & Good & Poor & Unacceptable/No \\
\hline Presentation, order, clarity & 8 & 6 & 7 & 1 \\
\hline Does the team answer all the questions? & 4 & 10 & 3 & 5 \\
\hline $\begin{array}{l}\text { If the team does not answer some of the questions, does } \\
\text { it justify the reason? }\end{array}$ & & & 1 & 14 \\
\hline $\begin{array}{l}\text { The team adds more concepts (questions) that are not on } \\
\text { the matrix }\end{array}$ & 1 & 5 & & 16 \\
\hline Has the team correctly cited its information sources? & 1 & 3 & 8 & 10 \\
\hline \multicolumn{5}{|c|}{ Indicators only for AEP and EWOC } \\
\hline $\begin{array}{l}\text { Does the team know how to separate the project } \\
\text { development and exploitation phases correctly? }\end{array}$ & 3 & 6 & 4 & 5 \\
\hline Has the team foreseen a realistic exploitation phase? & 2 & 7 & 3 & 6 \\
\hline Does the team consider the risks? & 4 & 5 & 2 & 7 \\
\hline
\end{tabular}


As can be seen in Table 6, six indicators have been designed to analyze the use of the Sustainability Matrix in the Sustainability Reports of the projects belonging to the three subjects, and three more indicators correspond only to the AEP and EWOC subjects. The results obtained in the indicators are briefly analyzed below.

- $\quad$ Regarding "Presentation, order, and clarity", only one of the reports is unacceptable, and $7(31.8 \%)$ are deficient (Poor). $63.6 \%$ of the projects have been evaluated as Excellent or Good.

- As regards answering all the questions individually, $63.6 \%$ of the reports do so in an excellent or good way, while $22.7 \%$ do not (Unacceptable). In addition, the teams that have not answered any of the questions have not justified the reason why they did not do so.

- The teams have not been creative, and $72.7 \%$ have limited themselves to answering the questions of the matrix, without asking themselves anything else.

- We have found serious deficiencies when citing the works used as reference. Only $18.2 \%$ of reports do this reasonably well (Excellent or Good).

- Regarding the separation between the Development and Exploitation phases, $50 \%$ of the reports have done so in an excellent or good way, while the other $50 \%$ do so in a poor or unacceptable way.

- Something similar happens when planning a realistic Exploitation phase. Only 50\% of the teams have been able to do it correctly (Excellent or Good).

- Finally, only $50 \%$ of the reports have made a satisfactory risk assessment (Excellent or Good).

\subsection{Discussion}

Students and engineers should feel confident about the consideration and assessment of the project sustainability. If the assessment is not properly conducted, the outcome may be useless or even counterproductive. Students and engineers should perceive the sustainability analysis of their projects as necessary and perfectly integrated into the project itself. If they are simply provided with a series of examples about how to assess the project sustainability, they may be restricted to choosing one example as a model and apply it without due reflection, merely considering sustainability as an external requirement for the project rather than as a professional requirement.

As imitation is one of the basic ways of learning for human beings, schools should make available to students several sustainability reports on a variety of different projects, in order to serve as an example and guide them towards composing their own Sustainability Reports. However, providing them with access to these reports without first explaining to them a set of guidelines such as the Sustainability Matrix is not an appropriate teaching practice, since students may tend to copy or adapt the style of one of the sample reports without reflecting properly on the sustainability of their project.

In the future, when the completion of a Sustainability Report in the DT becomes a regular practice in engineering schools, and both students and professors have fully recognized this need, it would probably be reasonable to consider withdrawing the example reports. However, this will only be possible when sustainability is fully integrated into the academic curriculum of the degree. When this happens, it is possible that these examples could be distributed throughout the curriculum, and in various subjects, in order to guide students in the relationship between sustainability and engineering.

It is also important that project sustainability should be taken into consideration from the moment of conception, in the planning phase. Analysis of whether or not a project is sustainable after it has been completed would prevent certain mistakes being made when designing new projects, although it would not guarantee that such mistakes would not be repeated. Sustainability must be taken into account in a project from the very outset, so that it forms part of the project design itself rather than a feature added later to comply with current legislation.

A good starting point could be to pose a series of questions aimed at making students think; not necessarily to elicit a correct or a single answer, but rather leading to the composition of a reasoned report responding to all the questions. If only a final report is required, it is likely that most students will evaluate sustainability at the end of the project, when in fact the goal is to be aware of the 
project sustainability from the very outset rather than assessing project sustainability on completion. The authors' proposal therefore is to raise questions concerning the different project phases, thereby encouraging students to think about how design decisions affect each stage of the project and the project in general.

The questions in the Sustainability Matrix are related to the 17 SDGs defined by UNESCO. However, from the point of view of engineering projects, the SDGs are not homogeneously identified with the three dimensions of sustainability. The Economic dimension is clearly the least reflected, since the questions in the Sustainability Matrix regarding this dimension are related to only three SDGs $(8,9$ and 12). On the other hand, the questions regarding the Environmental dimension are related to seven SDGs $(7,8,9,11,12,13$ and 17), and those concerning the Social dimension are related to twelve $(1,3,4,5,8,9,10,11,12,13,16$ and 17). Finally, four SDGs are not related to any of the questions in the Sustainability Matrix $(2,6,14$ and 15). Thus, it appears that the questions in the Sustainability Matrix are reasonably aligned with the SDGs.

A tool such as the Sustainability Matrix not only enables students to take sustainability into account during the project planning and project development, but also to organize and structure the Sustainability Report. The goal is to provide students with a tool to consider sustainability as part of their projects.

Regarding the DT of an engineering degree, students may use the answers to the questions in the Sustainability Matrix to qualitatively self-assess their projects, and teachers may also assess the project sustainability by analyzing the contents of the Sustainability Report. This evaluation should be qualitative and based on a rubric such as that used in the Barcelona School of Informatics (https://www.fib.upc.edu/sites/fib/files/documents/estudis/tfg_indicadors_rubriques_eng.html), given that objective indicators allowing a quantitative evaluation have not been defined.

A DT constitutes an academic undertaking limited in time, resources and depth, so such theses cannot be treated as a project carried out by an engineer. Students must be aware that their focus should be on the project (including sustainability), since that is what will be evaluated. Nevertheless, the aim is also for students to think carefully about the sustainability of the project as a whole. They are the engineers of the future, devoted to the design of large engineering projects, and as such they must understand that designing sustainable projects forms part of their work as professionals.

The work presented in this paper is aimed at providing engineering students with the training to include sustainability in their DTs. This training is fundamental for their future work as engineers. Even so, once they enter the labor market, engineers are required to use more powerful tools for introducing and evaluating the sustainability of their projects and organizations, such as for example the reports provided by the Global Reporting Initiative [6].

When analyzing the Sustainability Reports submitted by ETSETB students, it becomes clear that they are yet not sufficiently prepared to draw up critical and realistic Sustainability Reports of their engineering projects. A total of 50\% do not clearly differentiate the Development and Exploitation phases of a project, do not propose a realistic exploitation phase (over ambition) and are not able to conduct an appropriate project risk assessment.

Nevertheless, the Sustainability Matrix has all the makings of being a useful tool for taking sustainability into account in the projects in which students are engaged. We found that $63.6 \%$ of the project reports are well presented and respond individually to the questions in the Sustainability Matrix. However, only $27.3 \%$ of the teams have been able to raise issues that are not present in the matrix. Finally, it seems that students do not sufficiently assess the importance of citing information sources correctly, since only $18.2 \%$ of reports do it well. There is no doubt that students need to work more on this aspect during their studies.

\subsection{Limitations}

This study has some limitations. First, the Sustainability Matrix is aimed at integrating sustainability into engineering projects. The matrix presented in this paper is specifically designed for 
an engineering Degree, but it can be easily adapted projects of other degrees, such as those related to Economics and Business. A second limitation is that the framework presented in this paper is designed for a concrete reality: to help engineering students with little experience to introduce sustainability into a project. If students possessed prior experience, the framework could be more ambitious, so that, for example, the questions in the matrix could be answered holistically.

A third limitation is that the current framework has been in use for a very short time, so we have yet to acquire information about its real impact. While the initial results are promising, only in a near future we will know the real influence on student acquisition of sustainability competencies.

A final limitation is that this work is subject to the current situation, in which there is no international framework of indicators for assessing the sustainability of a DT. Should a reference framework be defined for assessing the sustainability of engineering projects in a degree, with clearly defined assessment indicators (such as the reference framework offered by GRI for companies), then these indicators could be considered for a quantitative sustainability assessment of DTs.

\section{Conclusions}

This paper presents a guide for introducing sustainability into the Degree (Bachelor's or Master's) Thesis of an Engineering Degree. With a little effort, the proposal could be adapted to Degrees other than engineering courses. It is based on the Sustainability Matrix, a 3-column, 3-row matrix in which the rows represent the three sustainability dimensions (Environmental, Economic and Social), and the columns set out some aspects of the project (Project Development, Project Exploitation and Project Risks). In accordance with the Socratic methodology, the cells of the matrix contain open questions which students must answer sequentially when preparing the Sustainability Report for their Degree Thesis. Students should reflect on these questions throughout the entirety of their projects. The purpose of the work proposed in this paper is therefore to encourage engineering students to think carefully about the consequences of their work. The proposal may produce a further impact, since it is expected that students will apply this framework to projects in which they may be engaged in the future, with the aim of making such projects more sustainable.

The future demands that all who inhabit and share our planet think and act in a sustainable manner. Engineers are at the forefront of this endeavor, and by including sustainability parameters in any projects they make undertake in their professional careers, they can contribute towards the creation of a more sustainable world. The integration of sustainability as part of an engineer's day-to-day professional practice is a form of expertise that must be acquired while they are at university, because the future will be sustainable or it will not be at all.

As future work, over the coming years, the authors intend to study the quality of sustainability reports of student projects and, if possible, the sustainability of the professional projects in which our graduates are actively engaged, an undertaking that should lead to a comprehensive evaluation of the impact of this proposal.

Author Contributions: Conceptualization, F.S.-C., D.L., C.M., E.V., J.C. (Jose Cabré) and J.C. (Joan Climent); Data curation, F.S.-C., D.L., C.M., E.V., J.C. (Jose Cabré) and J.C. (Joan Climent); Formal analysis, F.S.-C., E.V., J.C. (Jose Cabré) and J.C. (Joan Climent); Funding acquisition, F.S.-C. and C.M.; Investigation, F.S.-C., D.L., C.M., E.V., J.C. (Jose Cabré) and J.C. (Joan Climent); Methodology, F.S.-C., D.L., C.M., E.V., J.C. (Jose Cabré) and J.C. (Joan Climent); Project administration, F.S.-C.; Resources, F.S.-C., D.L., C.M., E.V., J.C. (Jose Cabré) and J.C. (Joan Climent); Supervision, F.S.-C., D.L., C.M., E.V., J.C. (Jose Cabré) and J.C. (Joan Climent); Validation, F.S.-C., D.L., C.M., E.V., J.C. (Jose Cabré) and J.C. (Joan Climent); Visualization, F.S.-C., D.L. and E.V.; Writing-original draft, F.S.-C., D.L., C.M., E.V., J.C. (Jose Cabré) and J.C. (Joan Climent); Writing-review \& editing, F.S.-C., D.L., C.M. and E.V. All authors have read and agreed to the published version of the manuscript.

Funding: This research was funded by the Spanish Ministerio de Economía y Competitividad under Grant EDU2015-65574-R, and by Spanish Ministerio de Ciencia, Innovación y Universidades, the Spanish Agencia Estatal de Investigación (AEI) and the Fondo Europeo de Desarrollo Regional (FEDER) under grant number RTI2018-094982-B-I00, from study design to submission. The funding source had no involvement in study design; in the collection, analysis and interpretation of data, in the writing of the report and in the decision to submit the paper for publication. 
Acknowledgments: We would like to thank the Barcelona School of Informatics and the Barcelona School of Telecommunications Engineering for their continuous support for this work. We also wish to thank Jordi Garcia and Marc Alier for their collaboration in the first stages of this work.

Conflicts of Interest: The authors declare no conflict of interest.

\section{References}

1. Brundland, G.H. Our Common Future. World Commission on Environment and Development; Oxford University Press: Oxford, UK, 1987.

2. UN SDG. United Nations Sustainable Development Goals. 2015. Available online: https://www.un: sustainabledevelopment/sustainable-development-goals/ (accessed on 11 May 2020).

3. UNESCO. Education for the Sustainable Development Goals: Learning Objectives; UNESCO: París, France, 2017; pp. 1-68. Available online: https://unesdoc.unesco:ark:/48223/pf0000247444 (accessed on 11 May 2020).

4. Directive 2014/95/EU of the European Parliament and of the Council of 22 October 2014. Available online: https://eur-lex.europa.eu/legal-content/EN/TXT/?uri=uriserv:OJ.L_.2014.330.01.0001.01.ENG\&toc= OJ:L:2014:330:TOC (accessed on 11 May 2020).

5. EU Press; European Commission. Press Release Database. 2013. Available online: http://europa.eu/rapid/ press-release_IP-13-231_en.htm (accessed on 11 May 2020).

6. GRI. 2018. Available online: https://www.globalreporting: (accessed on 11 May 2020).

7. GRI. Can Corporate Reporting Help End Poverty? 2019. Available online: https://www.globalreporting: resourcelibrary/GRI-Poverty-Study-Publication.pdf (accessed on 11 May 2020).

8. KPMG. The Road Ahead. The KPMG Survey of Corporate Responsibility Reporting. 2017. Available online: http://kpmg.com/crreporting (accessed on 11 May 2020).

9. Thürer, A.; Tomašević, I.; Stevenson, M.; Qu, T.; Huisingh, D. A systematic review of the literature on integrating sustainability into engineering curricula. J. Clean. Prod. 2018, 181, 608-617. [CrossRef]

10. Jones, N.; Roumeliotis, S.; Iosifides, T.; Hatziantoniou, M.; Sfakianaki, E.; Tsigianni, K.E.; Thivaiou, K.; Mpiliraki, A.; Evangelinos, I.K. Students' perceptions on environmental management of HEIs and the role of social capital. Int. J. Sustain. High. Educ. 2013, 14, 278-290. [CrossRef]

11. Friede, G.; Busch, T.; Bassen, A. ESG and financial performance: Aggregated evidence from more than 2000 empirical studies. J. Sustain. Financ. Investig. 2015, 5, 210-233. [CrossRef]

12. Kanth, R.K.; Liljeberg, P.; Tenhunen, H.; Amin, Y.; Chen, Q.; Zheng, L.; Kumar, H. Quantifying the environmental footprint of rigid substrate printed antenna. In Proceedings of the IEEE Conference on Technology and Society in Asia, Singapore, 27-29 October 2012; pp. 1-5. [CrossRef]

13. Sfakianaki, E. Resource-efficient construction: Rethinking construction towards sustainability. World J. Sci. Technol. Sustain. Dev. 2015, 12, 233-242. [CrossRef]

14. Giswatch. The Carbon Footprint of ICTs. 2010. Available online: https://www.giswatch:thematic-report/ sustainability-climate-change/carbon-footprint-icts (accessed on 11 May 2020).

15. ITU. ICTs and Climate Change, background paper. In Proceedings of the ITU Symposium on ICTs and Climate Change, Quito, Ecuador, 8-10 July 2009.

16. Gesi. Global E-Sustainability Initiative. The Opportunity. 2019. Available online: http://smarter2030.gesi: the-opportunity/ (accessed on 11 May 2020).

17. Accreditation Board for Engineering and Technology, Inc. (ABET). 2018. Available online: http://www.abet. org (accessed on 11 May 2020).

18. Tuning. Tuning Educational Structures in Europe. 2018. Available online: http://www.unideusto:tuningeu/ (accessed on 11 May 2020).

19. NTU. The "Performance Ranking of Scientific Papers for World Universities". 2019. Available online: http://nturanking.lis.ntu.edu.tw/ (accessed on 11 May 2020).

20. Miller, G. Exploring Engineering and Sustainability: Concepts, Practices, Politics, and Consequences. Eng. Stud. 2014, 6, 23-43. [CrossRef]

21. Lagesen, V.A. Workshop report: Engineers and sustainability: Achieving technological transitions, Trondheim, June 6-7, 2013. Eng. Stud. 2013, 5, 233-242. [CrossRef]

22. Ciampi, M.; Brito, C. Professional engineering education program. In Proceedings of the IEEE Frontiers in Education Conference, San Antonio, TX, USA, 18-21 October 2009; pp. 1-3. [CrossRef] 
23. Sinakou, E.; Pauw, J.B.; Goossens, M.; Van Petegem, P. Academics in the field of Education for Sustainable Development: Their conceptions of sustainable development. J. Clean. Prod. 2018, 184, 321-332. [CrossRef]

24. Hugé, J.; Mac-Lean, C.; Vargas, L. Maturation of sustainability in engineering faculties-From emerging issue to strategy? J. Clean. Prod. 2018, 172, 4277-4285. [CrossRef]

25. Leal Filho, W.; Shiel, C.; Paço, A.; Mifsud, M.; Ávila, L.V.; Brandli, L.L.; Molthan-Hill, P.; Pace, P.; Azeteiro, U.M.; Ruiz Vargas, V.; et al. Sustainable Development Goals and sustainability teaching at universities: Falling behind or getting ahead of the pack? J. Clean. Prod. 2019, 232, 285-294. [CrossRef]

26. Hu, Q.; Li, F.; Chen, C. A smart home test bed for undergraduate education to bridge the curriculum gap from traditional power systems to modernized smart grids. IEEE Trans. Educ. 2015, 58, 32-38. [CrossRef]

27. Clancy, E.A.; Quinn, P.; Miller, J.E. Assessment of a case study laboratory to increase awareness of ethical issues in engineering. IEEE Trans. Educ. 2005, 48, 313-317. [CrossRef]

28. Clancy, E.A.; Quinn, P.; Miller, J.E. Using case studies to increase awareness of, and improve resolution strategies for, ethical issues in engineering. In Proceedings of the 31st ASEE/IEEE Frontiers in Education Conference, Reno, NV, USA, 10-13 October 2001.

29. Diehl, J.C.; Boks, C.; Silvester, S. The evolution of design for sustainability courses. In Proceedings of the Fourth International Symposium on Eco Design. Environmentally Conscious Design and Inverse Manufacturing; IEEE Conference Publications: Tokyo, Japan, 2005; pp. 78-85.

30. Fleddermann, C.B. Engineering ethics cases for electrical and computer engineering students. IEEE Trans. Educ. 2000, 43. [CrossRef]

31. Stables, K. Educating for environmental sustainability and educating for creativity: Actively compatible or missed opportunities? Int. J. Technol. Des. Educ. 2019, 19, 199-219. [CrossRef]

32. López, D.; Sánchez, F.; Garcia, J.; Alier, M.; Piguillem, J.; Velasco, M. Introducing sustainability and social commitment skills in an engineering degree. In Proceedings of the Frontiers in Education Conference (FIE), Rapid City, SD, USA , 12-15 October 2011. [CrossRef]

33. Sánchez Carracedo, F.; Soler, A.; Martín, C.; López, D.; Ageno, A.; Cabré, J.; Garcia, J.; Aranda, J.; Gibert, K. Competency maps: An effective model to integrate professional competencies across a STEM curriculum. J. Sci. Educ. Technol. 2018, 27, 448-468. [CrossRef]

34. Miñano Rubio, R.; Uribe, D.; Moreno-Romero, A.; Yáñez, S. Embedding sustainability competences into engineering education. The case of informatics engineering and industrial engineering degree programs at Spanish universities. Sustainability 2019, 11, 5832. [CrossRef]

35. Solís-Espallargas, C.; Ruiz-Morales, J.; Limón-Domínguez, D.; Valderrama-Hernández, R. Sustainability in the university: A study of its presence in curricula, teachers and students of education. Sustainability 2019, 11, 6620. [CrossRef]

36. Ofei-Manu, P.; Didham, R.J. Identifying the factors for sustainability learning performance. J. Clean. Prod. 2018, 198, 1173-1184. [CrossRef]

37. Hedden, M.K.; Worthy, R.; Akins, E.; Slinger-Friedman, V.; Paul, R.C. Teaching sustainability using an active learning constructivism approach: Discipline-specific case studies in higher education. Sustainability 2017, 9 , 1320. [CrossRef]

38. Segalàs, J.; Ferrer-Balas, D.; Mulder, K.F. What do engineering students learn in sustainability courses? The effect of the pedagogical approach. J. Clean. Prod. 2010, 18, 275-284. [CrossRef]

39. Lozano, R.; Merrill, M.; Sammalisto, K.; Ceulemans, K.; Lozano, F. Connecting competences and pedagogical approaches for sustainable development in higher education: A literature review and framework proposal. Sustainability 2017, 9, 1889. [CrossRef]

40. Lozano, R.; Ciliz, N.; Ramos, T.; Blok, V.; Caeiro, S.; van Hoof, B.; Huisingh, D. Bridges for a more sustainable future: Joining Environmental Management for Sustainable Universities (EMSU) and the European Roundtable for Sustainable Consumption and Production (ERSCP) conferences. J. Clean. Prod. 2015. [CrossRef]

41. Ramos, T.B.; Caeiro, S.; van Hoof, B.; Lozano, R.; Huisingh, D.; Ceulemans, K. Experiences from the implementation of sustainable development in higher education institutions: Environmental management for sustainable universities. J. Clean. Prod. 2015, 106, 3-10. [CrossRef]

42. Rao, R.; Pawley, A.L.; Hoffmann, S.R.; Ohland, M.W.; Cardella, M.E. Development of a framework to Assess Sustainability Knowledge (ASK) in engineering undergraduate students. In Proceedings of the 40th IEEE Frontiers in Education Conference, Washington, DC, USA, 27-30 October 2010. 
43. Fargnoli, M. The assessment of the environmental sustainability. In Proceedings of the International Symposium on EcoDesign. Environmentally Conscious Design and Inverse Manufacturing, Tokyo, Japan, 8-11 December 2003; pp. 362-368.

44. Dickinson, D.A.; Mosovsky, J.A.; Caudill, R.J.; Watts, D.J.; Morabit, J.M. Application of the sustainability target method: Supply line case studies. In Proceedings of the Electronics and the Environment, 2002 IEEE International Symposium, San Francisco, CA, USA, 6-9 May 2002; pp. 139-143.

45. Valinejad, F.; Rahmani, D. Sustainability risk management in the supply chain of telecommunication companies: A case study. J. Clean. Prod. 2018, 203, 53-67. [CrossRef]

46. Badri Ahmadi, H.; Hashemi Petrudi, S.H.; Wang, X. Integrating sustainability into supplier selection with analytical hierarchy process and improved grey relational analysis: A case of telecom industry. Int. J. Adv. Manuf. Technol. 2017, 90, 2413-2427. [CrossRef]

47. Brent, A.C.; Labuschagne, C. Sustainable life cycle management: Indicators to assess the sustainability of engineering projects and technologies. In Proceedings of the IEEE International Engineering Management Conference, Singapore, 18-21 October 2004; Volume 1, pp. 99-103. [CrossRef]

48. Yonaidi, R.; Boosroh, M.H. Sustainability assessment of power plants projects firing on different fuels. In Proceedings of the 3rd International Conference on Energy and Environment, Malacca, Malaysia, 7-8 December 2009; pp. 215-220.

49. Feki, N.; Chabchoub, H. The ecological footprint as an assessment tool of the supply chain environmental performance case of a retail trade Tunisian company. In Proceedings of the International Conference on Advanced Logistics and Transport (ICALT), Hammamet, Tunis, Tunisia, 1-3 May 2014; pp. 222-228.

50. Rahman, A.A.L.A.; Islam, S.; Al-Nemrat, A. Measuring sustainability for an effective Information System audit from public organization perspective. In Proceedings of the IEEE 9th International Conference on Research Challenges in Information Science (RCIS), Athens, Greece, 13-15 May 2015; pp. 42-51.

51. Sánchez, F.; Cabré, C.; Alier, M.; Vidal, E.; López, D.; Martín, C.; Garcia, J. A learning tool to develop sustainable projects. In Proceedings of the IEEE Frontiers in Education Conference (FIE), Erie, PA, USA, 12-15 October 2016; pp. 1-9.

52. Sánchez, J.L.; González, C.S.; Alayon, S. Evaluation of transversal competences in the Bachelor Thesis in engineering. In Proceedings of the 22nd EAEEIE Annual Conference (EAEEIE), Maribor, Slovenia, 13-15 June 2011; pp. 1-5.

53. Vitner, G.; Rozenes, S. Final-year projects as a major element in the IE curriculum. Eur. J. Eng. Educ. 2009, 34, 587-592. [CrossRef]

54. Cassel, L.; Clements, A.; Davies, G.; Guzdial, M.; McCauley, R.; McGettrick, A.; Sloan, B.; Snyder, L.; Tymann, P.; Weide, B.W. Computer Science Curriculum 2008: An Interim Revision of CS 2001; Technical Report; ACM: New York, NY, USA, 2008.

55. Sánchez, F.; García, J.; López, D.; Alier, M.; Cabré, J.; García, J.; Vidal, E. El método socrático como guía del Trabajo de Fin de Grado. ReVisión 2013, 8, 53-62.

56. López, D.; Sánchez, F.; Vidal, E.; Pegueroles, J.; Alier, M.; Cabré, J.; Garcia, J.; García, H. A methodology to introduce sustainability into the Final Year Project to foster sustainable engineering projects. In Proceedings of the IEEE Frontiers in Education Conference (FIE), Madrid, Spain, 22-25 October 2014; pp. 1-7.

57. Felber, C. Die Gemeinwohl-Ökonomie-Das Wirtschaftsmodell der Zukunft; Deuticke: Wien, Austria, 2010; ISBN 978-3-552-06137-8.

58. Sustainable Meaures. 2014. Available online: http://www.sustainablemeasures.com/node/95 (accessed on 11 May 2020).

59. Sánchez Carracedo, F.; Climent, J.; Corbalán, J.; Fonseca, I.; Casas, P.; Garcia, J.; Herrero, J.R.; Rodriguez, H.; Sancho, M.R. A proposal to develop and assess professional skills in engineering final year projects. Int. J. Eng. Educ. 2018, 34, 400-413.

(C) 2020 by the authors. Licensee MDPI, Basel, Switzerland. This article is an open access article distributed under the terms and conditions of the Creative Commons Attribution (CC BY) license (http://creativecommons.org/licenses/by/4.0/). 